\title{
Educational aspects of the use of National Songs in Teaching Social Studies
}

\author{
Hala Ezz EI Dine, Imam Mohammed Ali and Nalaa Masuod Abd-Elbaky \\ Faculty of Education, South Valley University
}

\begin{abstract}
The article speaks about the educational aspects of national songs as the national song plays an important role in its deepening of events and tribulations. Its existence has been closely linked in various periods since the era of the pharaohs and until the modern era. It was the mirror that expresses the stages of struggle, events and revolutions that Egypt lived in. The eradication of feudalism, the rise of the revolutions, the wars, the construction of the High Dam, the victories witnessed by the country, the agreements and the unity between the country The song has an educational role where It has important functions and roles in human life in the emotional, civilizational, national, disciplinary, vocational and therapeutic aspects, in addition to its recreational role, by alleviating the burden of work and thinking. Therefore, the curriculum designed the teaching methods and created the educational, educational and cultural institutions.
\end{abstract}

Keywords: national songs; educational aspects; social studies

Citation El Dine et.al.,Requirements of Electronic Management in the Management of Kindergarten Institutions. SVU-Journal of abstract 2019, Vol.1: pp10 (retrieved from the Journal of Educational Sciences; 2018, No.34; pp 245) .

Copyright: Publisher South Valley University. This is an open access article distributed under the terms of the creative common attribution license, which permits unrestricted use, distribution and reproduction in any medium provided the original author and source are created. 